\title{
ANALISIS FAKTOR-FAKTOR YANG MEMPENGARUHI NIAT UNTUK BERDONOR DARAH SECARA REGULER DI UTD PMI KABUPATEN BANTUL YOGYAKARTA
}

\section{ANALYSIS OF FACTORS AFFECTING THE INTENTION TO DONATE BLOOD REGULARLY AT UTD PMI KABUPATEN BANTUL YOGYAKARTA}

\author{
Francisca Romana Sri Supadmi ${ }^{*}$, Nur'Aini Purnamaningsih², Rijantono Franciscus Maria ${ }^{3}$
}

\begin{abstract}
*1Universitas Jenderal Achmad Yani Yogyakarta, Jalan Brawijaya, Ring Road Barat, Ambarketawang, Gamping, Sleman, Yogyakarta 55294, email: siskatbd.ayani@gmail.com, Indonesia 2Universitas Jenderal Achmad Yani Yogyakarta, Jalan Brawijaya, Ring Road Barat, Ambarketawang, Gamping, Sleman, Yogyakarta 55294, email: nurainipurnamaningsih21@gmail.com, Indonesia 3UTD PMI Kabupaten Bantul, Jalan Jenderal Sudirman No.1, Babadan, Bantul, Yogyakarta 55711 email: rijantono1968@gmail.com, Indonesia
\end{abstract}

\begin{abstract}
Background: Blood supplies estimated to be around $2 \%$ of the total population 1 . However, only 1.88 million bags of blood can be met or $40 \%$ of the total needs, so there is a $60 \%$ lack of blood from the minimum requirement ${ }^{2}$.

Objective: The purpose of this study was to analyze the factors that influence the intention to donate blood regularly at UTD PMI Bantul Regency Yogyakarta using the Theory of Planned Behavior (TPB) approach.

Methods: This research was conducted at UTD PMI Bantul Regency, Yogyakarta in SeptemberDecember 2018. The number of respondents was 35 voluntary blood donors, with sampling techniques using accidental sampling.

Results: The results of multiple linear regression analysis show that attitudes, subjective norms, and behavioral control have a significant effect on the intention to donate. While the results of the regression analysis partially, based on a significant level of value, attitudes have a significant influence on one's intention in donating, while subjective norms and behavioral control do not significantly influence one's intentions in donating.

Conclusion: The attitude had the most significant influence on the intention to donate regularly on UTD PMI Bantul Regency Yogyakarta using the Theory of Planned Behavior (TPB) approach.
\end{abstract}

Keywords: Motivation, Blood Donation, TPB.

\section{PENDAHULUAN}

Dalam rangka mewujudkan derajat kesehatan masyarakat yang setinggitingginya, maka perlu diselenggarakan upaya kesehatan yang dilaksanakan melalui kegiatan pencegahan penyakit, peningkatan kesehatan, pengobatan penyakit dan pemulihan kesehatan. Penyelenggaraan upaya kesehatan tersebut salah satunya melalui kegiatan pelayanan darah. ${ }^{1}$

Pelayanan darah adalah upaya pelayanan kesehatan yang memanfaatkan darah manusia sebagai bahan dasar dengan tujuan kemanusiaan dan tidak untuk tujuan komersial. Pelayanan darah sebagai salah satu upaya kesehatan dalam rangka penyembuhan penyakit dan pemulihan kesehatan sangat membutuhkan ketersediaan darah atau komponen darah yang cukup, aman, bermanfaat, mudah diakses dan terjangkau oleh masyarakat. ${ }^{2}$

Darah sebagaimana dimaksud, diperoleh dari pendonor darah yang sehat 
dan memenuhi kriteria seleksi pendonor dan mengutamakan kesehatan pendonor. ${ }^{2}$ Sampai saat ini belum ada suatu pabrik atau industri di dunia ini yang sanggup membuat darah secara sintetis, maka tidak ada sumber lain dari pengadaannya hanya dari donasi secara sukarela yang dilakukan oleh para donor darah. ${ }^{3}$

Kebutuhan akan pelayanan darah semakin meningkat khususnya untuk menurunkan Angka Kematian Ibu (AKI), penanganan penyakit degeneratif, cedera akibat kecelakaan, penyakit darah (hemofilia, thalasemia), memerlukan transfusi darah untuk tujuan pengobatan dan pemulihan kesehatan pasien. ${ }^{3}$ Kebutuhan darah secara global dari tahun ke tahun mengalami peningkatan. Meskipun jumlah donasi darah juga terus mengalami peningkatan, namun peningkatan tersebut masih belum bisa memenuhi jumlah kebutuhan. Pada saat ini kebutuhan darah diperkirakan sekitar $2 \%$ dari jumlah total penduduk atau dalam hitungan angka mencapai sekitar 4,8 juta kantong darah dari 235 juta jiwa jumlah penduduk. ${ }^{4}$ Namun demikian, hanya dapat dipenuhi 1,88 juta kantong darah atau $40 \%$ dari jumlah kebutuhan tersebut, sehingga ada kekurangan darah $60 \%$ dari kebutuhan minimal. $^{5}$

Penelitian Ridwan dan Prasetyowati mengenai Faktor-Faktor yang Berhubungan dengan Pendonor Darah Sukarela di UTDC
PMI Kota Metro Tahun 2009 melaporkan bahwa dari 190 orang responden, proporsi pendonor darah sukarela sebesar $66,8 \%$, sebesar $67,4 \%$ tingkat pendidikan tinggi ( $\geq$ SMA), sebesar $52,1 \%$ responden memiliki pengetahuan kurang dan $62,6 \%$ responden memiliki sikap mendukung. ${ }^{6}$

Penelitian yang melaporkan tentang faktor-faktor yang mempengaruhi niat untuk berdonor darah secara reguler pada pendonor darah sukarela di UTD PMI Kabupaten Bantul belum pernah dilakukan. Oleh karena itu, dalam penelitian ini akan dilakukan penelitian untuk menganalisis faktor-faktor yang mempengaruhi niat untuk berdonor darah secara reguler di UTD PMI Kabupaten Bantul Yogyakarta dengan menggunakan pendekatan Theory of Planned Behavior (TPB).

Dengan model TPB sebagai kerangka untuk melakukan penelitian, dapat dijelaskan bahwa perilaku individu untuk melakukan tindakan tertentu yang spesifik, dalam hal ini adalah perilaku untuk berdonor darah secara reguler, dipengaruhi oleh niat (intention) (I) sebagai determinan tunggal untuk berperilaku tertentu (B). Niat untuk berperilaku dipengaruhi oleh 3 (tiga) faktor, pertama adalah behavioral belief (b), yaitu keyakinan akan hasil dari suatu perilaku (outcome belief) dan evaluasi (e) terhadap hasil perilaku tersebut. Keyakinan (b) dan evaluasi terhadap hasil (e) akan membentuk variabel sikap (attitude) 
terhadap perilaku (Ab). Kedua adalah normative belief $(\mathrm{Nb})$, yaitu keyakinan individu terhadap harapan normatif orang lain yang menjadi rujukannya seperti keluarga, teman, pimpinan atau orangorang yang penting dalam hidupnya dan motivasi untuk mencapai harapan tersebut (motivation to comply) (MC). Harapan normatif ini membentuk variabel norma subjektif (subjective norm) (SN) atas suatu perilaku. Ketiga adalah beliefs about ease or difficulty of control behavior atau disebut control belief (c), yaitu keyakinan individu tentang keberadaan hal-hal yang mendukung atau menghambat perilakunya dan persepsinya tentang seberapa kuat halhal tersebut mempengaruhi perilakunya (p). Control belief membentuk variabel kontrol perilaku yang dihayati (percieved behavioral control) (PBC).

\section{BAHAN DAN CARA PENELITIAN}

Penelitian ini dilakukan di UTD PMI Kabupaten Bantul Yogyakarta pada bulan September-Desember 2018. Populasi penelitian adalah seluruh pendonor yang melakukan donor darah di UTD PMI Kabupaten Bantul Yogyakarta. Sampel dalam penelitian berjumlah 35 responden dengan teknik pengambilan sampel menggunakan accidental sampling yaitu dengan mengambil responden yang kebetulan ada atau tersedia. Instrumen penelitian ini menggunakan kuesioner terstruktur yang dirancang berdasarkan konsep penelitian yang telah diuji validitas dan reliabilitasnya.

Metode analisis data dalam penelitian ini adalah metode analisis regresi linear berganda (multiple regression) untuk mengetahui besarnya pengaruh antara variabel bebas (sikap, norma subjektif dan kontrol perilaku) terhadap variabel terikat (niat untuk berdonor darah secara reguler), serta analisis regresi linear secara parsial untuk mengetahui pengaruh masing-masing variabel (sikap, norma subjektif dan kontrol perilaku) terhadap niat untuk berdonor darah secara reguler.

\section{HASIL DAN PEMBAHASAN}

Persyaratan donor menurut umur adalah usia 17-60 tahun bagi pendonor pertama dan sampai 65 tahun bagi pendonor berulang. Jumlah responden dalam penelitian ini sebanyak 35 responden, dimana responden merupakan pendonor darah sukarela yang melakukan tindakan berdonor darah di kantor UTD PMI Kabupaten Bantul, Yogyakarta. Data karakteristik responden didapatkan hasil seperti yang disajikan pada Tabel 1 . 
Tabel 1. Karakteristik Responden UTD PMI Bantul

\begin{tabular}{lcc}
\hline \multicolumn{1}{c}{ Variabel } & \multicolumn{2}{c}{ Jumlah Responden } \\
& Prekuensi & Persen (\%) \\
\hline JenisKelamin & 24 & 68,6 \\
Laki-laki & 11 & 31,4 \\
Perempuan & & \\
Pendidikan & 13 & 37,1 \\
Sarjana & 3 & 8,6 \\
Diploma & 16 & 45,7 \\
SMA & 1 & 2,9 \\
SMP & 2 & 5,7 \\
Lain-lain & & \\
Pekerjaan & 6 & 17,1 \\
Mahasiswa/ Pelajar & 12 & 34,3 \\
PNS/ Swasta & 7 & 20 \\
Wiraswasta & 2 & 5,7 \\
Buruh/ Tani & 8 & 22,9 \\
Lain-lain & & \\
KelompokUmur & 11 & 31,4 \\
17-26 Tahun & 11 & 31,4 \\
27-36 Tahun & 10 & 28,6 \\
37-46 Tahun & 3 & 8,6 \\
47-56 Tahun & 0 & 0 \\
57-66 Tahun & & \\
JumlahDonasi & 19 & 54,3 \\
1-10 & 6 & 17,1 \\
11-20 & 6 & 17,1 \\
21-30 & 1 & 2,9 \\
31-40 & 1 & 2,9 \\
41-50 & 0 & 0 \\
51-60 & 1 & 2,9 \\
61-70 & 0 & 0 \\
71-80 & 1 & 2,9 \\
81-90 & & \\
\hline
\end{tabular}

Berdasarkan jenis kelamin, pendonor terbanyak laki-laki sebanyak $68,6 \%$. Menurut tingkat pendidikan sebagian besar berpendidikan SMA $(45,7 \%)$, diikuti Sarjana $(37,1 \%)$, Diploma $(8,6 \%)$, lain-lain $(5,7 \%)$ dan SMP $(2,9 \%)$. Menurut jenis pekerjaan, distribusi responden sebagian besar didominasi PNS/swasta (34,3\%). Berdasarkan persyaratan usia donor dikelompokkan menjadi lima kelompok umur, yaitu kelompok I (17-26 tahun), kelompok II (27-
36 tahun), kelompok III (37-46 tahun), kelompok IV (47-56 tahun), dan kelompok V (57-66 tahun). Berdasarkan kelompok umur, mayoritas pendonor berusia 17-26 tahun dan 27-36 tahun (31,4\%). Berdasarkan informasi jumlah donasi dari formulir donor, responden dikelompokkan menjadi lima kelompok, yaitu kelompok I (1-10 donasi), kelompok II (11-20 donasi), kelompok III (21-30 donasi), kelompok IV (31-40 donasi), kelompok $\mathrm{V}$ (41-50 donasi), kelompok VI (51-60 donasi), 
kelompok VII (61-70 donasi), kelompok VIII (71-80 donasi), kelompok IX (81-90 donasi) dan kelompok $X$ (91-100 donasi). Berdasarkan jumlah donasi, frekuensi pendonor paling sering melakukan donor adalah kelompok I (1-10 donasi).
Hasil analisis regresi linear berganda pengaruh sikap, norma subjektif dan kontrol perilaku terhadap niat untuk berdonor darah secara regular disajikan pada Tabel 2.

Tabel 2. Hasil Analisis Linear Berganda Pengaruh Variabel Sikap, Norma Subjektif dan Kontrol Perilaku Terhadap Niat untuk Berdonor Darah secara Reguler

ANOVA $^{a}$

\begin{tabular}{|c|c|c|c|c|c|c|}
\hline Model & & $\begin{array}{l}\text { Sum of } \\
\text { Squares }\end{array}$ & Df & Mean Square & $\mathbf{F}$ & Sig. \\
\hline \multirow[t]{3}{*}{1} & Regression & 30.111 & 3 & 10.037 & 6.118 & $.002^{\mathrm{b}}$ \\
\hline & Residual & 50.860 & 31 & 1.641 & & \\
\hline & Total & 80.971 & 34 & & & \\
\hline
\end{tabular}

a. Dependent Variable: Niat

b. Predictors: (Constant), KontrolPerilaku, Norma Subjektif, Sikap

Dari Uji ANOVA menunjukkan taraf signifikansi sebesar 0,002 $<0,05$, sehingga variable sikap, norma subjektif dan kontrol perilaku berpengaruh signifikan terhadap niat untuk berdonor darah secara regular pada taraf signifikansi 0,05 . Hal ini sejalan dengan penelitian Supadmi, 2019 dimana taraf signifikansi kurang dari $0.05 .^{7}$

Hasil penelitian ini didukung oleh Teori Tindakan Terencana atau Theory of Planned Behavior (TPB) dari Ajzen ${ }^{8}$ dimana niat untuk berdonor darah yang pada gilirannya menjadi perilaku berdonor darah yang sesungguhnya, dipengaruhi oleh 3 (tiga) prediktor yaitu sikap, norma subjektif dan kontrol perilaku yang dihayati. Penelitian Masser et.al. ${ }^{9}$ melaporkan bahwa semua prediktor secara signifikan berkorelasi dengan niat untuk berdonor darah $(<0.01)$, niat untuk berdonor darah dalam 3 bulan ke depan menunjukkan hubungan terkuat dengan perilaku, dengan efektifitas diri, identitas diri sebagai donor darah, sikap, norma moral, penyesalan yang diantisipasi dan norma subjektif semua menunjukkan hubungan yang positif dengan perilaku berdonor darah. ${ }^{9}$ Penelitian Merav, B.N dan Lena, G. ${ }^{10}$ menunjukkan bahwa terdapat korelasi yang signifikan antara variabel sikap, norma subjektif, kontrol perilaku dan niat untuk berdonor darah, korelasi terkuat ditemukan antara niat dan kontrol perilaku $(r=0,60, p<0,01)$. Hasil regresi menunjukkan bahwa TPB menyumbangkan $36 \%$ niat untuk berdonor darah $(F=\quad(5.176)=19,72, \quad p<0,01)$. 
Penelitian Giles, et al. ${ }^{11}$ menunjukkan bahwa TPB bekerja sangat baik dalam memprediksi niat untuk berdonor darah. Variabel Sikap dan Norma Subjektif menyumbang $8 \%$ dari varian dalam niat dengan $F(2.96)=4.26, p=<0.005$ kemudian ditambahkan variabel self-efficacy dan kontrol perilaku yang dihayati pada langkah kedua memberikan kontribusi sebesar $64 \%$ dari varian dalam niat dengan $F$ $(2,94)=106,42, p=<0,001$.

Hasil analisis regresi linear secara parsial pengaruh masing-masing variabel (sikap, norma subjektif dan kontrol perilaku) terhadap niat untuk berdonor darah secara reguler ditunjukkan pada Tabel 3 .

Tabel 3. Hasil Analisis Regresi Linear secara Parsial Pengaruh Variabel Sikap, Norma Subjektif dan Kontrol Perilaku terhadap Niat untuk Berdonor Darah Secara Regular

Coefficients $^{a}$

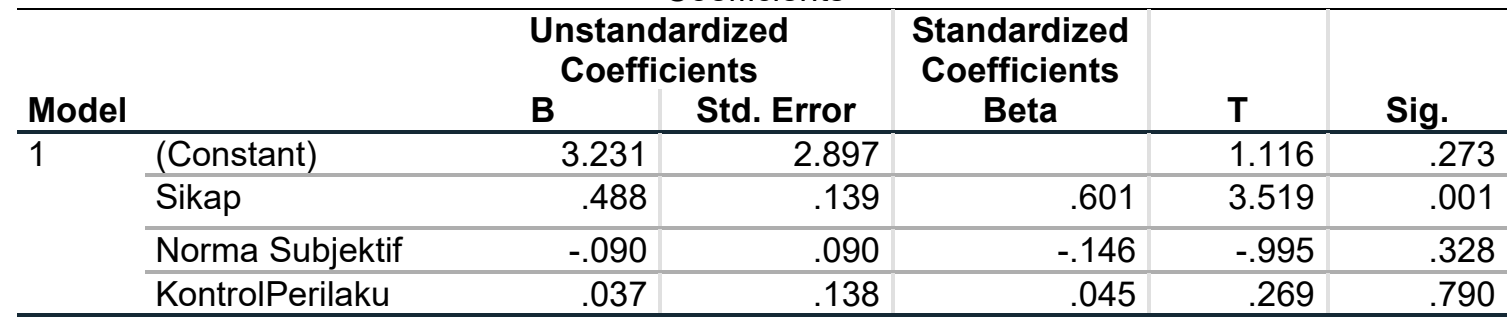

a. Dependent Variable: Niat

Hasil analisis regresi linear secara parsial taraf signifikansi menunjukkan 0,001 $<0,05$, sehingga sikap memiliki pengaruh yang signifikan terhadap niat seseorang dalam berdonor darah secara reguler. Sejalan dengan penelitian Supadmi, 2019 sebelumnya dimana variable sikap dengan taraf signifikansi 0.003 di bawah level of significanse $\quad(p<0.05){ }^{7} \quad$ Sikap dalam penelitian ini adalah reaksi perasaan mendukung atau tidak mendukung terhadap tindakan berdonor darah secara reguler. Variabel sikap dalam meningkatkan niat untuk berdonor darah secara reguler, terkait dengan faktor-faktor yang mempengaruhi terbentuknya sikap, misalnya pengalaman berdonor darah atau pengetahuan mengenai pentingnya berdonor darah secara reguler. Pengetahuan bisa diperoleh dari informasi yang disampaikan melalui orang lain yang dianggap penting, media massa, institusi atau lembaga pendidikan dan lembaga agama. Keberhasilan penyampaian informasi tergantung pada cara atau metode penyampaian yang tepat dan efisien sehingga mudah diterima dan mampu mempengaruhi sikap masyarakat.

Hasil analisis regresi linear secara parsial pengaruh variabel norma subjektif terhadap niat untuk berdonordarah secara regular dengan taraf signifikansi 0,328> 0,05 , sehingga dapat dikatakan bahwa variabel norma subjektif memiliki pengaruh yang tidak signifikan terhadap niat untuk 
berdonor darah secara reguler. Penelitian terdahulu Masser et.al. ${ }^{9}$ dan Supadmi, $2019^{13}$ juga menunjukkan bahwa norma subjektif tidak menjadi prediktor yang signifikan. Norma subjektif (subjective norm) adalah keyakinan seseorang mengenai perilaku apa yang diharapkan oleh orang lain dan motivasi untuk bertindak sesuai dengan harapan normatif. $^{12}$ Dalam penelitian ini, norma subjektif adalah keyakinan seseorang mengenai harapan orang lain dan motivasi untuk berdonor darah secara reguler. Harapan dan motivasi tersebut bisa disampaikan dalam bentuk ajakan untuk berdonor darah secara reguler pada kegiatan ceramah keagamaan, pertemuan-pertemuan warga atau melalui media massa dan elektronik. Pada penelitian ini sampel penelitian terbatas pada pendonor darah sukarela yang melakukan tindakan berdonor darah di kantor UTD PMI Kabupaten Bantul dengan karakteristik tingkat pendidikan mayoritas SMA $(45,7 \%)$ dan pekerjaan didominasi PNS/swasta (34,3\%), sehingga mayoritas melakukan tindakan berdonor darah semata-mata oleh karena niatnya untuk berderma dan tidak dipengaruhi oleh harapan dan motivasi dari orang lain.

Hasil analisis regresi linear secara parsial pengaruh variabel kontrol perilaku terhadap niat untuk berdonor darah secara regular menunjukkan taraf signifikan 0,790 $>0,05$ sehingga kontrol perilaku tidak berpengaruh signifikan terhadap niat seseorang dalam berdonor. Kontrol perilaku yang dihayati (percieved behavioral control) adalah persepsi atau keyakinan seseorang terhadap sulit tidaknya melaksanakan tindakan berdonor darah secara reguler. ${ }^{12}$ Keyakinan ini dapat berasal dari pengalaman berdonor darah di masa lalu atau berasal dari informasi tidak langsung mengenai tindakan berdonor darah tersebut, misalnya dengan melihat pengalaman orang lain yang pernah melakukannya. Faktor-faktor lain yang menurunkan niat untuk berdonor darah secara reguler, misalnya lokasi UTD yang jauh dari tempat tinggal, sehingga akan membutuhkan sumber daya baik waktu, tenaga dan biaya untuk menuju ke lokasi.

\section{KESIMPULAN}

Dari hasil penelitian mengenai analisis faktor-faktor yang mempengaruhi niat untuk berdonor darah secara reguler di UTD PMI Kabupaten Bantul Yogyakarta dengan menggunakan pendekatan Theory of Planned Behavior (TPB), karakteristik responden terbanyak berjenis kelamin lakilaki $(68,6 \%)$, sebagian besar berpendidikan SMA $(45,7 \%)$, distribusi responden didominasi PNS/swasta (34,3\%), mayoritas responden berusia 17-26 tahun dan 27-36 tahun $(31,4 \%)$, dan frekuensi pendonor paling sering melakukan donor adalah kelompok I (1-10 donasi). Hasil analisis regresi linear berganda menunjukkan bahwa sikap, norma subjektif, dan control 
perilaku berpengaruh signifikan terhadap niat untuk berdonor. Hasil analisis regresi secara parsial, sikap memiliki pengaruh yang signifikan terhadap niat seseorang dalam berdonor, sedangkan norma subjektif dan control perilaku tidak berpengaruh signifikan terhadap niat seseorang dalam berdonor.

\section{TERIMA KASIH}

1. dr. Kuswanto Hadjo, M.Kes, Dekan Fakultas Kesehatan Universitas Jenderal Achmad Yani Yogyakarta

2. Deby Zulkarnain RS, S.Kep., Ns., MMR, Ketua PPPM Fakultas Kesehatan Universitas Jenderal Achmad Yani Yogyakarta

3. dr. Rijantono Franciscus Maria, MPH., Kepala UTD PMI Kabupaten Bantul Yogyakarta

\section{KEPUSTAKAAN}

1. Undang-Undang Republik Indonesia Nomor 36 Tahun 2009 tentang Kesehatan. 2009.

2. Peraturan Pemerintah Republik Indonesia Nomor 7 Tahun 2011 tentang Pelayanan Darah. 2011.

3. Keputusan Menteri Kesehatan Republik Indonesia Nomor 423 Tahun 2007 tentang Kebijakan Peningkatan Kualitas dan Akses Pelayanan Darah (2007). Indonesia

4. Saputra, D. Direktori Donor Darah PMI Didirikan. Antara News, Yogyakarta; 2018. http.//antaranews.com/berita/ 279416/direktori-donor-darah-pmidiresmikan

5. Widiantoro, W. Kesadaran Masyarakat Masih Rendah. Kompas; 2018.

Retrieved from http://health.kompas.com/read/2011/06/ 11/02494828/

6. Ridwan, M dan Prasetyowati. FaktorFaktor yang Berhubungan dengan Pendonor Darah Sukarela di UTDC PMI Kota Metro Tahun 2009. Jurnal Kesehatan Metro Sai Melawai. 2009. Vol. 11 No.1 Edisi Juni 2009 ISSN; 19779-469X

7. Supadmi, F.R.S. Faktor-Faktor Yang Mempengaruhi Niat Untuk Berdonor Darah Secara Reguler di Unit Transfusi Darah Palang Merah Indonesia Kabupaten Gunungkidul. Jurnal Bhakti Setya Medika, Volume 3 No 1; 2018.

8. Ajzen. From intentions to actions: A theory of planned behavior. Action control: From cognition to behavior (J. Kuhl \& J. Beckman., pp. 1139).Heidelberg: Springer; 1991.

9. Masser, Barbara M. \& White, Katherine M. and Hyde, Melissa K. and Terry, Deborah J. and Robinson, Natali G. Predicting Blood Donation Intentions and Behavior Among Australian Blood Donors: Testing an Extended Theory of Planned Behavior Model. Transfusion, 49 (2). Pp. 320 - 329. 2009.

10. Merav, B.N \& Lena, G. Investigating The Factors Affecting Blood Donation Among Israelis. International Emergency Nursing. doi: 10.1016/j.ienj.2010.01.003; 2010.

11. Giles M, McClenahan, Cairns E, and Mallet J. An Application of The Theory of Planned Behavior to Blood Donation: The Importance of Self - Efficacy. Health Education Research, Theory \& Practice. Vol.19 no. 4 Pages 380 - 391. 2004.

12. Ajzen. From intentions to actions: $A$ theory of planned behavior. Action control: From cognition to behavior (J. Kuhl \& J. Beckman., pp. 1139).Heidelberg: Springer; 1985. 